\title{
Women Empowerment in Bangladesh: A Scenario Analysis
}

\author{
${ }^{1}$ Akhter Jahan, ${ }^{2}$ Shahnaz Begum \\ ${ }^{1}$ Assistant Professor Faculty of Business Administration University of Science \& Technology Chittagong \\ (USTC) Foy's Lake, Pahartali Chittagong - 4000, Bangladesh \\ ${ }^{2}$ Lecturer Faculty of Business Administration (FBA) University of Science \& Technology Chittagong (USTC) \\ Foy's Lake, Pahartali, Chittagong, Bangladesh
}

\begin{abstract}
Women are the worst sufferers in most of the less developed countries due to which their contribution often remains very negligible in the socio-economic development of country. This is obviously a serious limitation to the progress of such country. The empowerment of women can be a feasible solution to this burning problem. The present study in this regard is an endeavor to examine the necessity or WE by identifying the areas of women sufferings and placing appropriate recommendations in order to ensure sustainable development of the country.
\end{abstract}

Keywords: Women Empowerment, Women Sufferings, Socio-Economic Development.

\section{Introduction}

No effective development of a country is possible without holistic effort and contribution of her people irrespective of gender; ethnicity etc. being the half of the total population the role of women also bears much significance in this regard. However, women in this part of the world in general in Asia and in particular in Bangladesh are highly oppressed and suppressed. Violence, gender discrimination, confining within four walls of their residence for the so called cause of religion etc. are noteworthy aspects of women sufferings in Bangladesh. Amnesty International says at least one out of every three women has been beaten, coerced into sex, or abused in her lifetime. More than 60 million women are 'missing' from the world to day as a result of sex-selective abortions and female infanticide. Every year, millions of women are raped by parents, relatives, friends and strangers, employers and colleagues, soldiers and members of armed groups. ${ }^{1}$ Bangladesh is going through a crisis period of having a huge illiterate mass, highly discriminated gender issues, financial constraints, traditional society, illegal and unethical practices, and above all insecured environment for the women.

\section{Objective(s) of the Study}

The current paper is an embodiment of the research work carried on various aspects of the sufferings of women to draw a scenario analysis with a view to empowering women. The study mainly highlights scenario of women empowerment from the perspective of Bangladesh. The study also draws a conceptual and vivid description of women empowerment and places some recommendations for a series of feasible course of actions to overcome as well as prevent women sufferings resulting into women empowerment, the most effective approach for sustainable development.

\section{Methodology of the study}

The study is mainly based on secondary data collection from the relevant journals, websites of human rights related institutions, research papers, newspapers, magazines and the like. However, the observation and face to face discussion methods were also followed to reveal the primary feedback (i.e. data) of women in various spheres of the society in Bangladesh.

\subsection{Women Empowerment}

\section{Theoretical Framework}

Empowerment is a word that has been used so often and so widely that its definition has become blurred. Activist groups use the term to rally behind different issues, while academic circles frequently cite the word in scholarly articles.

The term really took off with literature discussing empowerment of marginalized peoples, such as women and the poor, and especially with regards to community development. For example, in 1983 the Women's Studies International Forum discussed empowerment of women in "Power and Empowerment". From then until now, the literature has increasingly been focused on these issues. In 2010, articles were published entitled "Power and empowerment: Fostering effective collaboration in meeting the needs of orphans and vulnerable children" and "Women empowerment through the SHG approach" that demonstrate just a few ways how empowerment is being discussed in the academic community. 
Women empowerment ensures the self-decision regarding education, participation, mobility, economic independency, public speaking, awareness and exercise of rights, political participation and many more factors. In short women empowerment is the braking of personal limitation.

UNDP coordinates global and national efforts to integrate gender equality and women's empowerment into poverty reduction, democratic governance, crisis prevention and recovery, and environment and sustainable development.The Women's Empowerment Principles are a set of Principles for business offering guidance on how to empower women in the workplace, marketplace and community. They are the result of a collaboration between the United Nations Development Fund for Women (UNIFEM, part of UN Women) and the United Nations Global Compact. The development of the Principles included an international multi-stakeholder consultation process, w hich was launched in March 2009.

\subsection{Process of Empowering Women}

One way to deploy the empowerment of women is through land rights. Land rights offer a key way to economically empower women, giving them the confidence they need to tackle gender inequalities. Often, women in developing nations are legally restricted from their land on the sole basis of gender. Having a right to their land gives women a sort of bargaining power that they wouldn't normally have, in turn; they gain the ability to assert themselves in various aspects of their life, both in and outside of the home.

Another way to provide women empowerment is to allocate responsibilities to them that normally belong to men. When women have economic empowerment, it is a way for others to see them as equal members of society. Through this, they achieve more self-respect and confidence by their contributions to their communities. Simply including women as a part of a community can have sweeping positive effects.

Participation, which can be seen and gained in a variety of ways, has been argued to be the most beneficial form of gender empowerment. Political participation may be the ability to vote and voice opinions, or the ability to run for office with a fair chance of being elected, plays a huge role in the empowerment of peoples.

It is argued that Microcredit also offers a way to provide empowerment for women. Governments, organizations, and individuals have caught hold of the lure of microfinance. They hope that lending money and credit allows women to function in business and society, which in turn empowers them to do more in their communities. One of the primary goals in the foundation of microfinance was women empowerment. Loans with low interest rates are given to women in developing communities in hopes that they can start a small business and provide for her family.

Empowerment includes the following, or similar, capabilities:-

- The ability to make decisions about personal/collective circumstances

- The ability to access information and resources for decision-making

- Ability to consider a range of options from which to choose (not just yes/no, either/or.)

- Ability to exercise assertiveness in collective decision making

- Having positive-thinking about the ability to make change

- Ability to learn and access skills for improving personal/collective circumstance.

- Ability to inform others' perceptions though exchange, education and engagement.

- Involving in the growth process and changes that is never ending and self-initiated

- Increasing one's positive self-image and overcoming stigma

- Increasing one's ability in discreet thinking to sort out right and wrong

\subsection{Significance of Women Empowerment}

Empowering women usually involves giving them opportunity for better education. With that, fertility rates decrease, as well as infant mortality rates. Literate women have other opportunities in life other than marriage and motherhood, such as being part of the work force. Delaying marriage usually also means that women have less fertile years, which naturally decreases the number of children they can have. They are also better informed about family planning options, although it seems that religion plays a stronger part in this aspect other than simple literacy.

Literate women are more than another mouth to feed in poor families living in less developed countries. Instead of being seen as a liability, and therefore being married off as soon as possible, they can become a valuable asset to their families. Of course, at a personal level, empowerment gives women a chance to make their own choices, challenge the worthiness of old traditions, and to actually look for opportunities away from their families and villages.

Several points are key in addressing this issue of culture in relation to efforts to foster gender equality and women's empowerment. 
- First, all development efforts, including those that seek "merely" to introduce new technologies or promote economic growth, imply social change, for, as the nature, modes, goals and social relations of production are altered, structures of work and family life are transformed.

- Second, women's empowerment was first articulated and championed as an approach to development by southern women seeking to improve their lives and those of their families.

- Third, culture is not a static, fixed entity, but a confluence of beliefs and values continuously undergoing processes of change and redefinition in response to external and internal economic, political and social forces.

\subsection{Sufferings of women in Bangladesh}

\section{Scenario Analysis of Women Empowerment in Bangladesh}

In reality the condition of women in Bangladesh is not satisfactory at all. They are often oppressed and suppressed due to many socio-economic obstacles that are prevailing in the country. Some of the instances of violence against women are as follows:

Acid attack on women

It has been a common phenomenon in Bangladesh. Usually good-looking young girls are the victims. Common causes are love affairs, forced marriage, dowry from bride's parents, personal reasons and refusal of illegal sexual relations and enmity over land properties, According to the statistics of the Survivors Foundation, Bangladesh, the number of acid attacks was 136 in 1999, 222 in 2000, 341 in 2001, 485 in 2002 and 410 in 2003.

ii) Gender Discrimination:

It is a dark chapter of women sufferings in Bangladesh. The trend of sexual harassment of women in the last couple of years indicates that it knows no boundary irrespective of professions, social strata and levels of income. According to the English Daily 'The Bangladesh Observer' dated 25th December 2001, there were 733 and 961-recorded cases of rape in Bangladesh respectively in the year of 1997 and 1998. Recently a human rights organization named Odhikar has reported that 62 women were raped in May 2004. Of them four were killed after rape and two-committed suicide. ${ }^{2}$

iii)

\section{Prostitution:}

It is considered as immoral and shameful act in a civilized country. But in Bangladesh, there are 60,000 $-1,00,000$ people in prostitution ${ }^{6}$ and more than $25 \%$ girls working in different brothels are under the age of 18 years, $95 \%$ of those girls are trafficked under the age of 18 and about $25 \%$ are under the age of $12 .{ }^{3}$

\section{iv) Trafficking of women:}

One of the glaring examples among many difficulties of women's in Bangladesh is trafficking. Often women are abducted and trafficked illegally to other country like India, Pakistan, and Middle East. ${ }^{4}$ Moreover, since the country does not have proper birth registration system, it complicates the rescue, release and repatriation of trafficked women within the territory and out of border. ${ }^{4}$ According to the police estimate more than 15,000 women and children are smuggled out of Bangladesh every year. ${ }^{5}$

\section{v) Low voice of women in decision-making:}

It is disgraceful for the personality of Bangladeshi women in general. It is because they are very seldom given the opportunities to express ideas for execution and as a result the economic and social values of the women are not reflected in the household decision making and leadership. ${ }^{6}$ Furthermore, less priority to female child such as less love and affection, less nutritious food, less budget for education, etc., makes them poor fellow. The birth of a female child is even rarely considered as a happy incident and if women cannot have a male child, usually the husband remarries. ${ }^{4}$

\section{vi) Working condition:}

Working condition is more severe in garment factories of Bangladesh as most of the workers are young women and gender inequality is prevalent in the country. ${ }^{7}$ In many cases women garment workers must work 12 hours a day ( 8 a.m. -8 p.m.), sometimes as much as two hours more and often seven days a week. ${ }^{8}$ But in the field survey, it has been discovered that they often get the wages much low in percentage than the World Bank defined extreme poverty earning amount US\$ 1 per day. In 2000, women received, on average, US\$1.07 per day compared to US\$ 1.39 per day for men i.e., about 30 percent less. In agricultural activities, the disparity is observed to be more pronounced with women bagging wages which is 42 percent lower than men and in nonagricultural pursuits, it was 24 percent lower. ${ }^{9}$

The other acute lacking of working environment of Bangladesh is that no standard exists in its readymade garments (RMG) sector. For instance, due to the lack of fire-safety codes for the garment industry 252 garment workers died and several thousands more were injured in 54 fires that broke out in different garment factories of Bangladesh from 1990 to $2002 .^{10}$ 
vii) $\quad$ Reproductive health service:

Bangladesh is still going through a crisis period in providing reproductive health service. In spite of enormous programs and their significant success in the country's population control and reproductive health care service during the last decade three women still have been dying every hour because of complications related to pregnancy and childbirth. ${ }^{11}$ In the backdrop of this situation it has been discovered that $23 \%$ of the country's total population are adolescents, of them $48 \%$ are married. Nearly, $57 \%$ of the married becomes mothers before reaching 19 years. Besides, $92 \%$ birth is delivered at home and only $13 \%$ of the birth is assisted by medically trained personnel. ${ }^{4}$

\subsection{Empowerment in Bangladesh: Few Remarkable Steps}

The micro-credit program of Grameen Bank has been positioned strongly in empowering women of Bangladesh in particular. In Bangladesh the Grameen Bank micro-credit program in collaboration with the other NGOs accounts to 65 percent of the total micro-credit facilities being provided in the country. Now many other NGOs and even the Government have launched micro-credit program(s) with differentiation to their project profile and varied needs and wants of the clients. In this year's non-development budget the Government has for the first time allocated an amount of BDT 34.5 million for micro-credit program of different Government Departments. Besides, under the Development Budget, various Ministries, Departments, NGOs are implementing micro-credit program involving about BDT 520 million.

NGOs like Karitas and Grameen Bank are such poverty alleviation that empowers the financial capability of the women through the distribution of easy installment basis loan(s) from their rural local branches. Likewise, Karitas and Grameen Bank, Bangladesh Government under Shabuz Chata and Surjeyr Hashi (i.e. Laughing of the Sun) marked program distributes medicines and counsels health information to the rural women through their rural or local branches. Merie Stope clinic is such an organisation in city and urban areas for health related counseling services for women.

Government is playing a vital role through social advertisement to promote the idea of women empowerment. Bangladesh Television (BTV) advertisements on legal actions against ill practices such as acid throwing, rape and other social discrimination are some remarkable instances of women empowerment idea promotion.

\section{Recommendations}

Some recommendations have been offered below in respect of some cases of such evaluation:

6.1. In the present context of Bangladesh, it is not so easy to implement the idea of women empowerment program. For instance, it has become a common practice in mass media (viz. private TV and cable channels) to appoint the women as models of different products in an objectionable way. In many cases for financial security and so called name and fame the hired women employees put on short skirts or half-nude dresses and try to trigger impulse buying of customers. Though this empowers them financially, empowerment in true sense cannot be ensured with this.

If educated people including women or social organizations come forward and give stress on building women's consciousness then businessmen will be back footed in taking such chances. It is because exposing and displaying body do not mean that one is modern and smart. These in turn may destroy the dignity of the women.

6.2. Now-a-days heinous crimes like acid throwing, rape, physical torture, etc., are common violence on the women of Bangladesh. Proper application of the existing laws may improve the condition. But overall condition will not be satisfactory in the long run until and unless the ruling tendency or imposed restrictions on women to keep them staying within the four walls of the house as the docile daughter or the cute wife of ruling husband is not changed. A satisfactory condition in the long run will be ensured only then when effective emphasis will be given on "Education For All" program. Still then, women oppression will not be stopped and equality will not be ensured if good instances of punishment for crime are not focused and education in improving our mental health does not work. Both Government and NGOs in this case have the roles to be played in arranging strong campaigns against violence on women and organize demonstrations and rallies on a regular basis.

6.3. By being promoted with the idea of women empowerment Bangladeshi women, who used to be busy with their household works and stay within the four walls of their house, are taking education today and working in different professional arenas. But this rate is still very poor. A national consensus if can be developed (i.e. not only in paper / documents but also in real life) and programs like financial assistance, entrepreneurship and educational development, etc., can be implemented in a successful way, the rights of the women will be ensured which will ultimately recognize the women as equal partner in developing a country.

6.4. There are some financial assistances (viz., micro-credit/finance) and poverty alleviation (viz., rural development by Grameen Bank) programs prevailing in Bangladesh. Most of these programs are directed to 
rural people especially poor women so that they can improve their economic condition. But from the field survey it has been found that the husbands or the other males of the family often force their wives or other female relations in getting loans under these programs and thereby take away the same for the other purpose. As a result, effectiveness of these programs is hampered. The authority concerned with these programs has to be more careful in sanctioning financial assistances. Otherwise the main objective of the program will suffer from the improper usage and in result the marketing process of women empowerment idea will be left unutilized.

6.5. Infertility is still considered as the fault of the women. It has also been found from the study that countrymen even in this modern era are exercising old, traditional and wrong beliefs. In some cases, they even do not hesitate to apply fotowa. For example, during the field survey some respondents (i.e. women) regretted that after their marriage when they came in their father-in-law's house and any accident took place immediate after that then they were made liable for that. In fact, it is nothing but a wrong ideology that the people are bearing in their mind till today. Government, NGOs, social organizations and women's organizations must have to come forward with the various informative programs like public awareness campaign, organizing women, advocacy and advisory work, media exposure to provide financial, wealth and health news and guidelines, protection techniques for unwanted pregnancies, etc. Besides, those organizations must give emphasis on eradicating the wrong and old beliefs of traditional people so that the rate of oppression or wrong treatment against women can be lowered and finally stopped.

6.6. In the field survey it has also been discovered that though the rate of women's participation is increasing in professional arena, they are still limited at lower levels as personal assistant, receptionists, security guards, salesgirl, etc. As a result, the idea of women empowerment program stands as nothing else but eyewash. According to a renowned chemist, the uneven competition of women against more qualified men with foreign degrees or perhaps with PhDs should be eliminated. If it is not possible, then the advertisements should not contain misleading clauses of "Females are especially encouraged to apply" or "Equally qualified women will get preference". These illusions must be stopped and all the potential employers should be as honest as possible when advertising for a position, which is not really intended for women. To ensure clarity management authority should not hesitate to appoint competent women and increase their number. The negative mentality of men to accept women as colleagues or seniors also needs to be changed.

6.7. In order to uplift the status of women a meaningful involvement of women is required in the policy making process as well as other socio-economic measures. For this purpose the provision of 15 reserved seats for women MPs for 10 years was incorporated in the Bangladesh constitution in 1972. With the 5th amendment in 1979 the number of reserved seats was increased from 15 to 30 . When this period expired on 10 December 1987 and the 4th Parliament (1988) had no reserved seats for women, the 10th amendment (1990) was made with the provision of 30 reserved women seats for a further period of 10 years. This period also expired on 5th April 2001. Recently with the 14th amendment a new provision of 45 reserved women seats for the next 10 years has been introduced. Basically, these women MPs have nothing to do but act as puppets in the pursuit of political gains of the concerned parties, which select them. This in consequence leads them to suffer from inferiority complex regarding their status, rights and responsibilities in the positions that they hold. But the introduction of such provision in no way can improve the condition of women. Instead, the political parties should reach a consensus to conduct the direct election of present reserved seats in the Parliament if they really want to ensure basic democracy and empower the women by improving their leadership and managerial capacity.

Since it is the age of Information and Communications Technology, electronic media can be utilized to a great extent to promote any idea like women empowerment program within a very short period of time and at cheap cost. Theaters and cable TV dramas on this issue are also significant.

\section{Conclusion}

The issues discussed above give us an idea that women, the half of the total population of Bangladesh are suffering from various reasons irrespective of very silly family matters to highly important socio-economic affairs. These in turn have made them feeling insecured, worried and confused about their future, which ultimately hinder the overall development process. In such a situation if they are not brought into the mainstream of the development programs by giving priority on their equal rights and safety, a true national development will never be possible to achieve. For this purpose, as a part of human resource development program the concept of women empowerment needs to be implemented with priority. 


\section{References}

[1] Amnesty International Magazine (2004), Issue 124.

[2] Wijaya annangara, Paper on Cultural Violation, Retrieved from http://www.sdnpbd.org/sli/international_day /women_day/2003/problems.htm

[3] Islam Shahin, opcit.

[4] Ibid

[5] Difficulties of Women's in Bangladesh, Retrieved from

http://www.sdnpbd.org/sli/international_day/women_day/2003/problems.htm

[6] Bayes Abdul (April 27, 2004), Women: Changing roles and realizing rights, The Daily Star.

[7] Zohir, S.C. \& Paul Majumder. O. (1996), Garments Workers in Bangladesh: Economic, Social and Health Condition, Bangladesh Institute of Development Studies (BIDS), Research Monograph No. 18, Dhaka, Bangladesh.

[8] Chepesiuk Ron (May 19, 2004), South Asia's Women garment workers: Globalization's race to the bottom, The Daily Star.

[9] Bayes Abdul, opcit.

[10] Chepesiuk Ron, opcit.

[11] BSS (May 24, 2004), 3 (Three) women die of pregnancy related complications every hour, Dhaka, The New Age.

\section{Bibliography}

[1] Selina Mohsin (June 11, 2004), Working in partnership for the empowerment of women, Weekend: The Little Magazine, Independent.

[2] The Independent (June 11, 2004), Special Credit Programme for Employment Generation, Text of proposed budget 2004-2005.

[3] Staff Correspondent (June 2, 2004), No let up in cruelty against women, The New Age. 